\title{
Nitrogen leaching losses from fodder beet and kale crops grazed by dairy cows in southern Southland
}

\author{
L Chris SMITH $^{1 *}$ and Ross M MONAGHAN ${ }^{2}$ \\ ${ }^{1}$ AgResearch Woodlands, 204 Woodlands-Morton Mains Road, RD 1 Invercargill, New Zealand \\ ${ }^{2}$ AgResearch, Invermay Agricultural Centre, Private Bag 50034, Mosgiel, New Zealand \\ *Corresponding author: chris.smith@agresearch.co.nz
}

\begin{abstract}
Fodder beet has become increasingly common as both a winter forage and as a supplement at the shoulders of the dairy season in southern New Zealand. One advantage over the more traditional kale crop option is that fodder beet results in less urinary nitrogen $(\mathrm{N})$ excretion in dairy animals, potentially reducing $\mathrm{N}$ leaching. Two trials were undertaken to measure nitrogen leaching losses under both autumn-grazed or autumn-lifted fodder beet crops. Leaching losses were also measured from winter-grazed fodder beet and winter-grazed kale treatments. Results from Trial 1 show that leaching losses from autumn-lifted or autumn-grazed fodder beet treatments were large $\left(108-131 \mathrm{~kg} \mathrm{~N} \mathrm{ha}^{-1}\right)$ relative to losses measured in the winter-grazed fodder beet treatment $\left(82 \mathrm{~kg} \mathrm{~N} \mathrm{ha}^{-1}\right)$. This indicates that autumngrazed fodder beet crops have a greater potential for $\mathrm{N}$ leaching than winter-grazed fodder beet. The practice of lifting and removing fodder beet during autumn appeared to reduce $\mathrm{N}$ leaching somewhat, but losses were still relatively large, perhaps due to carryover of $\mathrm{N}$ from the previous season as a result of the dry summer conditions that preceded the drainage season in in the first year of Trial 1. The amount of $\mathrm{N}$ leached from the winter-grazed fodder beet treatment from Trial 1 at $82 \mathrm{~kg} \mathrm{~N}^{-1}$ was $50 \%$ less than the $176 \mathrm{~kg} \mathrm{~N}^{-1}$ observed for the kale crop. Results from Trial 2 using larger plots showed a similar trend, with winter-grazed fodder beet leaching $42 \%$ less $\mathrm{N}$ than winter-grazed kale (41 vs $70 \mathrm{~kg} \mathrm{~N} \mathrm{ha}^{-1} ; \mathrm{P}<0.001$ ), despite not all the urine $\mathrm{N}$ being collected by the end of the drainage season. These losses are relatively large compared to the annual $\mathrm{N}$ leaching losses measured from pasture paddocks on the same farm, which ranged from 13-23 $\mathrm{kg} \mathrm{N} \mathrm{ha}{ }^{-1}$. Considerations of grazing and/or harvest timing (autumn vs winter) as well as crop type appear to be important factors that determine $\mathrm{N}$ leaching losses from Southland dairy systems.
\end{abstract}

Keywords: winter forage crop grazing, cattle, soil N, nitrate leaching, crop lifting.

\section{Introduction}

The southern region of New Zealand faces a number of challenges around how and where to winter stock.
Traditionally, non-lactating in-calf dairy cows have been wintered off pasture on brassica crops. This practice occurs over an approximately 10 -week period during winter, and brassica crops are a cost-effective strategy for providing the required amounts of winter feed and for limiting the extent of animal treading damage to soils and pastures during the cool and wet winters. Research has shown that grazing brassica crops can be a significant source of $\mathrm{N}$ transfers to waterways (Smith et al. 2012; Monaghan et al. 2013; Malcolm et al. 2015). This is predominantly due to large amounts of excreta $\mathrm{N}$ being deposited onto bare soil during winter crop grazing, when plant uptake of $\mathrm{N}$ is low and drainage is high (Talbot et al. 2020). Winter cropping activities are therefore increasingly coming under greater scrutiny for their potential contribution to the impact of farming on water quality.

Brassica crops such as swedes (Brassica napus) and kale (Brassica oleracea) have traditionally been the mainstay of such winter grazing systems in southern New Zealand but fodder beet (Beta vulgaris; FB) has become increasingly popular as both a winter forage crop or as a feed source on the shoulders of the milking season (Dalley et al. 2020). When used for the latter, it can either be grazed in situ or lifted and fed elsewhere to milking cows (Gibbs 2014). Harvested FB can also be stored for up to 3 months and fed out in spring as a supplement during early lactation (Gibbs et al. 2015). In addition to its high yield potential, an advantage of FB is its relatively low Crude Protein (CP) content which can lower urinary nitrogen (UN) concentrations (Dalley et al. 2017) and has the potential to reduce UN excretion when fed as a supplement to cows in late lactation (Dalley et al. 2020; Waghorn et al. 2019). Reduced UN excretion is expected to result in less $\mathrm{N}$ leaching over the winter grazing period (Malcolm et al. 2016; De Ruiter et al. 2019).

Autumn feeding of FB to cows in late lactation could increase the risk of $\mathrm{N}$ leaching since all growing plants are removed at a time when drainage is likely to occur, thus $\mathrm{N}$ that might have been taken up by the growing crop is at risk of leaching from the soil. Malcom et al. (2020) observed that relatively large amounts of soil mineral $\mathrm{N}$ remained following autumn grazing of $\mathrm{FB}$ crops that were fallow over the subsequent winter. 
Sowing a catch crop or lifting and removal of fodder beet plants were found to reduce this $\mathrm{N}$ accumulation in soil. Evaluation of the composite effects of autumn-feeding of FB on $\mathrm{N}$ loss to water is still to be tested at the scale of a grazing system. This scale of experimentation is needed to ensure that the full effects of crop choice, crop yield and resulting winter stocking rate are measured, as other plant-animal interactions may exert important influences on soil processes that affect $\mathrm{N}$ leaching. This includes the effect of reductions in urinary $\mathrm{N}$ concentrations, which may help to reduce the high concentrations of $\mathrm{N}$ within the urine patch, and in turn the risk of $\mathrm{N}$ leaching and emission of nitrous oxide (Di et al. 2016). In addition, further evaluation is needed on the impact of secondary plant metabolites, excreted in urine or exuded through the roots, on soil $\mathrm{N}$ processes (de Klein et al. 2020) and consequently $\mathrm{N}$ leaching risk.

Given there is much interest in the environmental impacts of forage crop systems in general, and the productive performance of FB in particular, a study was initiated in 2018 on the effects of winter crop type (FB $\mathrm{v}$ kale) and grazing timing (autumn $\mathrm{v}$ winter) or lifting $\mathrm{FB}$ on $\mathrm{N}$ leaching losses. Measurements of $\mathrm{N}$ leaching from adjacent pastures on the same farm were taken to provide some context on the relative importance of crop versus pastoral contributions to $\mathrm{N}$ losses from the whole-farm system.

\section{Materials and Methods \\ Trial location}

The site chosen for the experiment was the Southern Dairy Hub (SDH), a research farm near Wallacetown in Southland (46.309 S, 168.318 E). This farm is a 349-ha facility developed with investment from southern dairy farmers, AgResearch and DairyNZ, and operates as a working dairy farm as well as a site for research to support the local dairy industry. The area of the farm used for this experiment was on an Edendale typic firm brown soil, classed as well drained, with moderate over slow permeability and low $\mathrm{N}$ leaching vulnerability.

\section{Experimental design and management \\ Trial 1. $2018-2019$ \\ Fodder Beet}

A randomised plot design was set out within a paddock containing FB established out of pasture using standard commercial cultivation practices, with three treatments allocated to this area. The treatments were FB either grazed or lifted in May (autumn), or grazed in early July (winter). There were 5 replicate plots for the lifted treatment (nil urine return) and 10 replicates for the grazed treatments. Grazed plots were $6 \mathrm{~m} \times 4 \mathrm{~m}$ and lifted plots $2 \mathrm{~m} \times 4 \mathrm{~m}$ with five or three ceramic cups installed per plot for the two treatments, respectively (equivalent to 2083 or 3750 cups $\mathrm{ha}^{-1}$ respectively). Differences in plot size and replication were due to the need to match animal area requirements for the grazing treatments within the limited area allocated for the trial. In the first year, autumn lifting of the crop occurred on 2 May and grazing occurred on 4 May. Rising 2-year-old (R2) heifers that had been transitioned onto FB during the preceding week were used to graze these autumn treatments. The heifers grazed the trial plots for 75 minutes during mid-morning, which was considered sufficient time to ensure animal intake met daily FB allocation (Table 1). This grazing imposed an equivalent grazing intensity of about 3 RSU hours $\mathrm{m}^{-2}$ (Relative Stock Units, where one heifer was assumed to represent 5 RSUs; Parker, 1998). Grazing intensity is used here as a metric to standardise the potentially confounding effects of differences between treatments and measurement years in grazing duration, stock type (heifer versus mature cow) and crop yields and allocations per animal (Moir et al. 2011). This calculation is particularly informative for illustrating the effects of the short duration of the autumn grazing and the relatively high grazing intensity required for eating the high-yielding FB crops.

Winter grazing plans were changed due to very wet soil conditions and small plot sizes which meant the 24hour grazing period for FB scheduled for the first year of Trial 1 was not possible. Grazing was limited to a 12-hour period, which occurred on 6 July 2018. This reduced grazing duration resulted in a grazing intensity of only $18 \mathrm{RSU}$ hours $\mathrm{m}^{-2}$ instead of the targeted 35 RSU hours $\mathrm{m}^{-2}$ that would have occurred over a 24hour period (Table 1) with 'typical' soil conditions. The targeted urine load was instead achieved by applying additional artificial urine to plots; assuming 10 urinations per cow per day over winter, it was calculated that 21 urinations had been missed per plot (Ravera et al. 2015). A solution containing urea (2.5 g N $\mathrm{L}^{-1}$ ) was therefore applied in a randomised grid layout and at a rate of 2.4 litres patch $^{-1}$ (Ravera et al. 2015) to simulate targeted urinary $\mathrm{N}$ returns at the planned grazing intensity.

\section{Winter-grazed kale}

The layout of the kale trial in 2018 was a simple block of 10 plots $(6 \mathrm{~m} \mathrm{x} 4 \mathrm{~m})$ with 5 ceramic cups per plot (2083 cups ha-1) in a first year out of pasture kale paddock. The design meant that the cows grazed the plots as part of their normal daily feed break. This grazing occurred at the same time as the winter FB grazing on 6 July 2018, with cows on the trial area for 24 hours before the area was fenced off from the rest of the break. Break size was determined according to crop yield and per head allocation. Due to the variable crop yield across the paddock, coupled with the number of 
Table 1 Crop yields, feed allocations and calculated grazing intensities (RSU hours $\mathrm{m}^{-2}$ ) for the two trials.

\begin{tabular}{|c|c|c|c|c|c|c|c|c|}
\hline Trial & Treatment & $\begin{array}{l}\text { Crop yield } \\
(\mathrm{t} \mathrm{ha-1})\end{array}$ & $\begin{array}{c}\text { Crop N } \\
(\%)\end{array}$ & $\begin{array}{l}\text { Daily feed } \\
\text { allocation } \\
\left(\mathbf{k g ~ c o w}^{-1}\right)\end{array}$ & $\begin{array}{l}\text { Daily crop } \\
\text { allocation } \\
\left(k^{-1} \text { cow }^{-1}\right)\end{array}$ & $\begin{array}{c}\text { Actual crop } \\
\text { intake } \\
\left(\text { kg cow }^{-1}\right)\end{array}$ & $\begin{array}{c}\text { Targeted }^{\mathrm{a}} \\
\text { daily } \\
\text { grazing } \\
\text { intensity } \\
\text { (RSU hours } \\
\mathrm{m}^{-2} \text { ) }\end{array}$ & $\begin{array}{c}\text { Actual } \\
\text { grazing } \\
\text { intensity } \\
(\mathrm{RSU} \text { hours } \\
\left.\mathrm{m}^{-2}\right)\end{array}$ \\
\hline \multirow[t]{3}{*}{1} & Autumn FB & 24.4 & 1.74 & 10.9 & 3.0 & 3.2 & 3.0 & 2.6 \\
\hline & Winter FB & 20.4 & 1.88 & 14.2 & 11.3 & 5.9 & 35.0 & $18.0^{\mathrm{b}}$ \\
\hline & Winter kale & 15.6 & 2.70 & 14.8 & 7.9 & 12.6 & 19.2 & 16.1 \\
\hline \multirow[t]{3}{*}{2} & Autumn FB & 23.4 & 1.71 & 15.2 & 3.0 & 3.0 & 3.0 & 3.4 \\
\hline & Winter FB & 20.4 & 1.59 & 14.1 & 10.6 & 8.9 & 34.7 & 32.3 \\
\hline & Winter kale & $8.8^{c}$ & 3.70 & 14.8 & 11.0 & 8.0 & 20.6 & 21.1 \\
\hline
\end{tabular}

stock available and the size of the feed-break offered to the herd, grazing intensity was not optimised. Hence it was calculated that an extra 4 urinations were also required per plot to achieve an equivalent grazing intensity for cows grazing kale (Table 1; Ravera et al 2015). A solution containing urea was therefore applied as described above.

In November 2018, following the winter drainage period, and in line with normal practice for the farm, both paddocks were cultivated using a rotary hoe, without disturbing the ceramic cups. A second forage crop of kale was then sown into the FB trial area, and a crop of FB into the kale trial area.

\section{Trial 2. 2019-2020}

To improve the statistical robustness of the study, a second trial was designed with both $\mathrm{FB}$ and kale treatments in the same area within a first year out of pasture FB paddock. The four treatments (autumnlifted FB, autumn-grazed FB, winter-grazed FB, wintergrazed kale) were laid out in a randomised block design with 12 replicates. Plot size was increased to $40 \mathrm{~m}^{2}$ $(8 \mathrm{~m} \times 5 \mathrm{~m})$ for the grazed plots and $16 \mathrm{~m}^{2}(8 \mathrm{~m} \times 2 \mathrm{~m})$ for the lifted plots. Once FB plants had emerged, seedlings were removed from the designated kale plots and kale seed was hand sown. Ceramic cups were installed at a sampling intensity of 2000 cups ha $^{-1}$ in late summer once the kale crop had established.

Lifting and grazing (mid-morning) of the autumn FB treatments occurred on 1 May 2019 and 9-10 May respectively. Winter grazing of the FB and kale treatments occurred on 26 and 27 June respectively. In each case, animal numbers per plot were set to meet dietary requirements of that particular herd, be it fodder beet or kale. Cows were taken from appropriate herds to ensure that they received a continuous crop diet.
Baleage was supplied as required to ensure dietary intake did not change while animals were on the experimental area. The grazing intensities (RSU hours $\mathrm{m}^{-2}$ ) achieved in this trial were slightly below target for the winter-grazed $\mathrm{FB}$, but slightly higher than targeted for the autumn-grazed $\mathrm{FB}$ and winter-grazed kale (Table 1). All grazing was conducted under AgResearch Invermay animal ethics approval AEC14694.

\section{Pasture sites}

In order to compare $\mathrm{N}$ losses from cropped areas with losses from the rest of the farm, cups were also installed in three pasture paddocks belonging to one of the four farmlets at SDH. These paddocks were grazed over the milking season as part of the normal rotation, with cows removed and placed onto crop for the months of June and July.

\section{Crop yield measurements}

Yield measurements of the crops were obtained immediately prior to grazing and/or lifting by means of harvesting a $1 \mathrm{~m}^{2}$ quadrat from one location in each of the smaller lifted plots and two locations in the grazed plots. Fodder beet bulbs were pulled from the ground with excess soil removed prior to weighing. Kale plants were cut at ground level. The crop harvested was weighed with a sub-sample retained and dried at $65^{\circ} \mathrm{C}$ for dry matter determination with the dried samples sent to a commercial laboratory for $\mathrm{N}$ determination by thermal conductivity detection (Rayment \& Lyons 2011). Fodder beet bulbs and tops were dried and analysed separately. Following each grazing, the amount of residual crop left by the animals was also determined in the same fashion. Differences between pre-grazing crop yields and residuals left after grazing were used as estimates of actual animal crop intakes, as presented in Table 1. 


\section{Measurements of $\mathrm{N}$ leaching losses and soil inorganic $\mathrm{N}$ contents}

Porous ceramic cups (Webster et al. 1993) were used to determine nitrate leaching below a soil depth of $600 \mathrm{~mm}$. These were installed at a $45^{\circ}$ angle into paddocks and plots sown with fodder beet or kale, or into paddocks (3) containing established pasture. Cups in the crop paddocks were installed at a density of 1 cup per $3-5 \mathrm{~m}^{2}$, which equates to an equivalent density of more than 2000 cups ha ${ }^{-1}$. Coupled with the high degree of plot replication, it was assumed that this density of ceramic cups would be sufficient given the variability and challenges of this method for measuring leaching losses at a field scale (Lilburne et al. 2012). There were initially 20 cups installed in 2018 into each of the pastoral paddocks in a diagonal transect, with a further 20 cups installed per transect in 2019.

Leachate was collected from the porous cups for every $25-30 \mathrm{~mm}$ of surplus rainfall, as calculated by a soil water balance model (WBM). Negative pressure (approximately $-60 \mathrm{kPa}$ ) was applied to sampling ports for at least 18 hours before removing all the collected soil solution. Leachate samples were stored frozen before being thawed for analysis of nitrate- $\mathrm{N}$ $\left(\mathrm{NO}_{3}-\mathrm{N}\right)$ and ammonium- $\mathrm{N}\left(\mathrm{NH}_{4}-\mathrm{N}\right)$ concentrations using a Skalar $\mathrm{SAN}^{++}$segmented flow analyser (Skalar Analytical B.V., Breda, Netherlands). Samples collected within 2 weeks of grazing were also analysed for urea; however, none was detected. A daily soil-water balance (FAO 2000) was used to determine total daily surplus water volumes (hereafter referred to as drainage) and soil water deficit values at the site. Rainfall data were sourced from the meteorological station at $\mathrm{SDH}$, while potential evapotranspiration data (ET) were obtained from the Invercargill meteorological station located 10 $\mathrm{km}$ south of the field site.

Soil inorganic N contents were measured 10 to 14 days after each grazing/lifting event. Depending on the plot size, 4-10 soil cores ( $25 \mathrm{~mm}$ dia.) were collected from each plot. These cores were separated into $0-100$, 101-200, 201-300, and 301-600 mm depths, sieved (4-mm mesh width) and mixed before $40 \mathrm{~g}$ was placed in a jar with $200 \mathrm{~mL}$ of $2 \mathrm{M} \mathrm{KCl}$ and shaken for one hour (Mulvaney 1996). Extracts were then filtered and analysed for $\mathrm{NO}_{3}-\mathrm{N}$ and $\mathrm{NH}_{4}-\mathrm{N}$ concentrations using a Skalar $\mathrm{SAN}^{++}$segmented flow analyser. Remaining soil was dried to determine gravimetric soil moisture contents. Soil cores were also taken from treatments for determination of bulk density, as described by Drewry and Paton (2000), to allow calculations of soil inorganic $\mathrm{N}$ content per unit area and soil depth.

\section{Statistical analysis}

Results were statistically analysed by ANOVA using Genstat v18. Statistical tests were confined to fodder beet treatments for the first year of study because kale and fodder beet treatments in Trial 1 were not truly spatially replicated.

\section{Results \\ Rainfall and drainage}

Rainfall for 2018 at $900 \mathrm{~mm}$ was lower than the longterm average of $1050 \mathrm{~mm}$, although modelled drainage was reasonably typical at $417 \mathrm{~mm}$ for the autumngrazed crop and $390 \mathrm{~mm}$ for the winter-grazed crops (Figure 1). Rainfall in 2019 was slightly higher at $940 \mathrm{~mm}$, with modelled drainage being $447 \mathrm{~mm}$ for the autumn-grazed crop and $430 \mathrm{~mm}$ for the wintergrazed crops. The 2018 drainage season was from May to December which was uncharacteristically late, with almost $40 \%$ of annual drainage occurring during September through to November. Drainage in 2019 also commenced in May, although the total for the month was relatively small $(10 \mathrm{~mm})$ compared to that estimated for May in $2018(78 \mathrm{~mm})$. Due to above average summer rainfall, the initial drainage season for Trial 2 did not finish until February 2020.

\section{Crop yields, grazing intensities and $\mathbf{N}$ intakes}

The FB yield in 2018 was $24.4 \mathrm{t} \mathrm{DM} \mathrm{ha}^{-1}$ in May, but this had dropped, due mainly to leaf loss, to $20.4 \mathrm{t} \mathrm{DM}$ $\mathrm{ha}^{-1}$ by the beginning of July when the winter grazing occurred. In contrast, the 2018 kale crop yielded 15.6 t DM ha-1 (Table 1). The 2019 FB crop yielded $23.4 \mathrm{t} \mathrm{ha}^{-1}$ in May and $20.4 \mathrm{t} \mathrm{DM} \mathrm{ha}^{-1}$ at the June grazing. The 2019 kale crop was low-yielding due to being established a month late. At only $8.8 \mathrm{t} \mathrm{DM} \mathrm{ha}^{-1}$ it was considerably lower yielding than the $2018 \mathrm{crop}$ and lower than the median kale yield at the farm of $11.8 \mathrm{t}$ $\mathrm{DM} \mathrm{ha}^{-1}$. Additional kale was hand-harvested from a neighbouring kale paddock and fed to cows grazing the winter kale treatments to bring the kale offered to the animals up to their required daily allocation, assuming they were grazing a crop yielding $11.8 \mathrm{tDM} \mathrm{ha}^{-1}$.

The diet of animals grazing during autumn was different for Trial 1 compared to Trial 2 (Figure 2). Due to the cows already transitioning onto their winter 2018 diet, it consisted of mainly FB with baleage, while in 2019 it was predominantly pasture supplemented with FB and baleage. Intakes from these other feed sources were therefore included in the calculated estimates of daily DM and $\mathrm{N}$ intakes for the full 24-hour grazing interval (Figure 2). For the autumn grazing in Trial 2, the pasture contribution to $\mathrm{N}$ intake meant that total daily $\mathrm{N}$ intake was closer to that of the winter-grazed kale than the winter-grazed FB treatment (Figure 2B).

In the winter of Trial 1 , the FB animals were fed solely crop for the 12-hour grazing period, but did have access to baleage during the previous 12 hours. In contrast, the kale animals had access to baleage and 


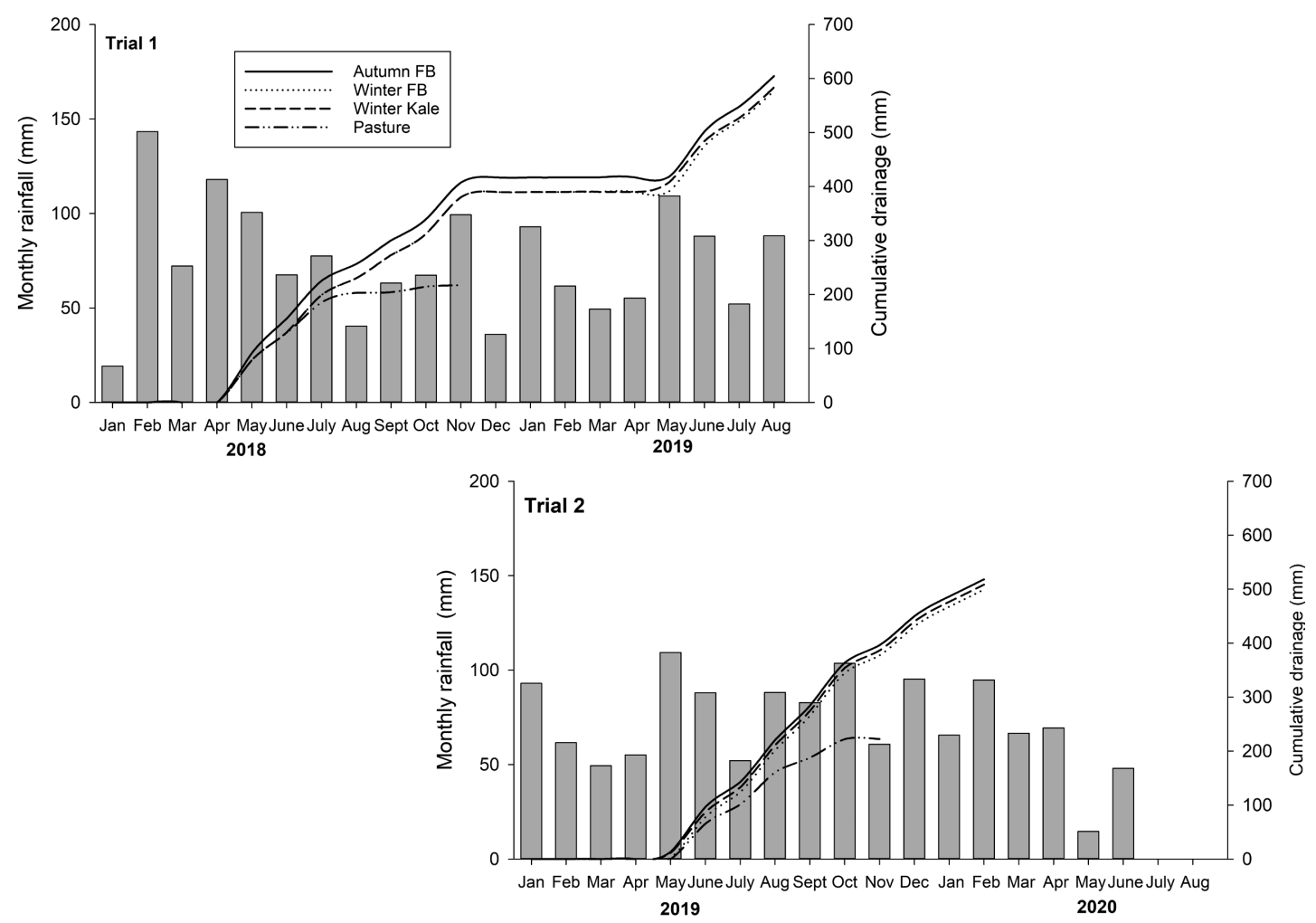

Figure 1 Monthly rainfall (bars) and cumulative drainage (lines) derived from a water balance model for the 20 months of Trial 1 and 12 months of Trial 2. Note that modelled drainage for the two trials differs in 2019 due to the effects of different crop sowing dates on evapotranspiration values used in the water balance model.

PKE while grazing the experimental area. The higher than expected DM intake in 2018 for the kale-fed animals (Table 1, Figure 2A) was the result of overallocation of kale, due to variability of yield within the paddock. Winter intakes for Trial 2 are those measured from the grazing of the experimental area. While DM intakes were similar, the $\mathrm{N}$ intakes were considerably less for the winter-grazed FB compared to the wintergrazed kale for both years.

\section{Soil inorganic $\mathbf{N}$}

Soil inorganic $\mathrm{N}$ was higher under the autumn-grazed FB than under the lifted treatment in Trial $1(\mathrm{P}=0.031$; Table 2), but higher under the lifted treatment in Trial $2(\mathrm{P}=0.019)$. Soil inorganic $\mathrm{N}$ levels under wintergrazed FB were similar to those under the autumn FB treatments; levels were however considerably higher under the kale treatments. This was particularly evident in Trial 1 where the topsoil $(0-200 \mathrm{~mm})$
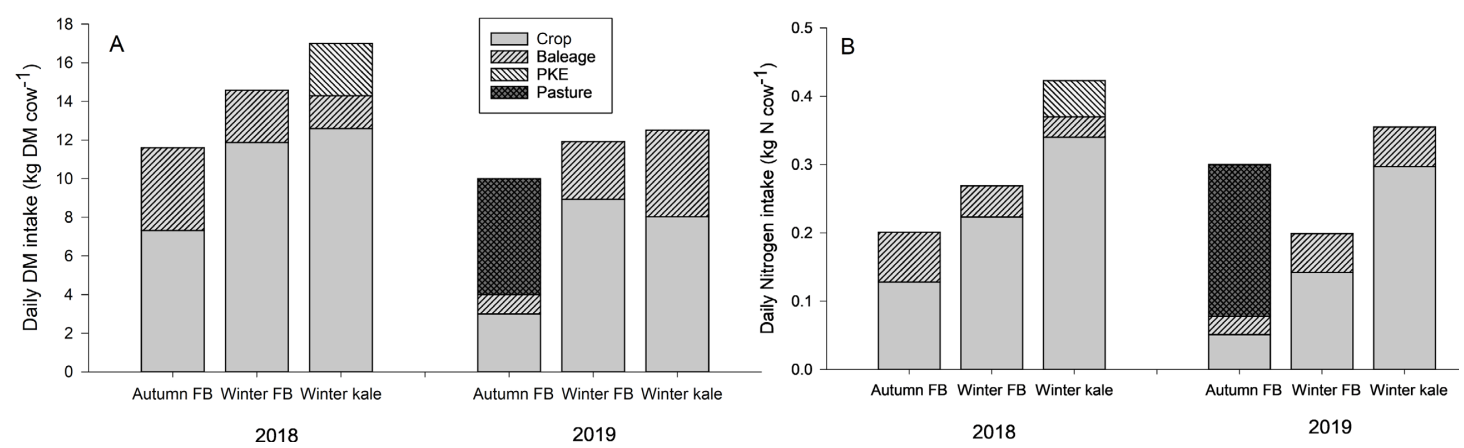

Figure 2 Estimated or measured daily $(\mathrm{A})$ dry matter $\left(\mathrm{kg} \mathrm{DM} \mathrm{cow}{ }^{-1}\right)$ and $(\mathrm{B})$ nitrogen intakes $\left(\mathrm{kg} \mathrm{N} \mathrm{cow}^{-1}\right)$ for cows on the different crop grazing treatments during the two trials. 
Profile soil inorganic $\mathrm{N}$ contents $\left(\mathrm{kg} \mathrm{N} \mathrm{ha}^{-1}\right) 10$ to 14 days after grazing/lifting under autumn-lifted, autumn-grazed and winter-grazed FB and winter-grazed kale treatments. P-values are given where possible (bold if significant; statistical tests between FB and Kale were not possible in Trial 1 due to the non-randomised layout of the latter treatment).

\begin{tabular}{|c|c|c|c|c|c|c|}
\hline \multirow[b]{2}{*}{ Depth } & \multicolumn{3}{|c|}{ Autumn } & \multicolumn{3}{|c|}{ Winter } \\
\hline & Lifted & Grazed & $P$ value & FB & Kale & $P$ value \\
\hline \multicolumn{7}{|l|}{ Trial 1} \\
\hline 0-100 mm & 14 & 21 & 0.130 & & & \\
\hline $101-200 \mathrm{~mm}$ & 11 & 18 & 0.124 & & & \\
\hline 0-200 mm & & & & 46 & 188 & \\
\hline $201-300 \mathrm{~mm}$ & 12 & 16 & 0.252 & 123 & 33 & \\
\hline $301-600 \mathrm{~mm}$ & 37 & 52 & 0.071 & 53 & 59 & \\
\hline 0-600 mm & 74 & 107 & 0.031 & 112 & 280 & \\
\hline \multicolumn{7}{|l|}{ Trial 2} \\
\hline $0-100 \mathrm{~mm}$ & 7 & 17 & 0.003 & 24 & 44 & $<0.001$ \\
\hline $101-200 \mathrm{~mm}$ & 10 & 5 & $<0.001$ & 5 & 7 & 0.110 \\
\hline 0-200 mm & 8 & 3 & $<0.001$ & 3 & 5 & 0.079 \\
\hline $201-300 \mathrm{~mm}$ & 18 & 5 & $<0.001$ & 13 & 24 & 0.065 \\
\hline $301-600 \mathrm{~mm}$ & 43 & 31 & 0.019 & 45 & 81 & $<0.001$ \\
\hline
\end{tabular}

contained $188 \mathrm{~kg} \mathrm{~N} \mathrm{ha}^{-1}$; under winter-grazed FB it only contained $46 \mathrm{~kg} \mathrm{~N} \mathrm{ha}^{-1}$ (Table 2). This difference in soil inorganic $\mathrm{N}$ between kale and winter-grazed $\mathrm{FB}$ was significantly different in Trial $2(\mathrm{P}<0.001)$. Also of note are the greater amounts of soil inorganic $\mathrm{N}$ below $300 \mathrm{~mm}$ depth in all treatments in Trial 1, which may have contributed to the greater leaching losses than observed for Trial 2.

\section{Leaching losses of $\mathbf{N}$}

When drainage commenced in May 2018 (Trial 1), concentrations of $\mathrm{N}$ in leachate were $9.3 \mathrm{mg} \mathrm{N} \mathrm{L}^{-1}$ for the autumn-lifted $\mathrm{FB}$ treatment and $21.9 \mathrm{mg} \mathrm{N} \mathrm{L}^{-1}$ for the autumn-grazed FB treatment (Figure 3). Concentrations then increased steadily before peaking at 34 and $31 \mathrm{mg} \mathrm{N} \mathrm{L}^{-1}$ at the end of the drainage season in November, for the two treatments, respectively, following around $330 \mathrm{~mm}$ of drainage. Initial concentrations in May were also higher for the kale treatment than for the winter FB treatment at $17.8 \mathrm{mg} \mathrm{N} \mathrm{L}^{-1}$ and $10.2 \mathrm{mg} \mathrm{N} \mathrm{L}^{-1}$, respectively. There was a steep increase in leachate $\mathrm{N}$ under the kale treatment immediately following grazing as a result of a large spike of $\mathrm{NH}_{4}-\mathrm{N}$. When drainage ceased in November, concentrations for the July grazed FB treatment had reached $24 \mathrm{Mg} \mathrm{N} \mathrm{L}^{-1}$ and the kale treatment $29 \mathrm{mg} \mathrm{N} \mathrm{L}^{-1}$. Once drainage recommenced in late May 2019 (the second year of Trial 1), concentrations for all the FB treatments dropped to near background levels while for the kale treatment they continued to increase, peaking at $41 \mathrm{mg} \mathrm{L}^{-1}$ before dropping. In excess of $700 \mathrm{~mm}$ of drainage was required over a period of 16 months before the $\mathrm{N}$ concentration of leachate under the kale treatment had dropped to levels measured prior to the cows grazing the crop.

Initial $\mathrm{N}$ concentrations for Trial 2 were relatively low (Figure 3), with the exception of the lifted FB treatments. The elution curves are not complete at this stage as the trial is still being sampled but it is noticeable that concentrations under the kale treatment increased at a greater rate than other treatments. When the drainage season ended in February 2020 (the second year of Trial 2), concentrations had reached 27 and $37 \mathrm{mg} \mathrm{L}^{-1}$ for the winter- and autumn-grazed FB treatments, respectively. Concentrations in the autumn-lifted FB and kale treatments at this time were approx. $35 \mathrm{mg} \mathrm{L}^{-1}$.

The estimated amounts of $\mathrm{N}$ leached from the crop treatments and pasture sites are shown in the bar graphs presented in Figure 4 and show some consistent effects between treatments and measurement years. The first is that losses from the autumn FB treatments were significantly $(\mathrm{P}<0.05)$ greater than from the wintergrazed FB treatment. Secondly, losses from the wintergrazed kale treatment were greater (and statistically significant for Trial 2) than measured from the wintergrazed FB treatment. As expected, $\mathrm{N}$ leaching losses from the pasture paddocks were much lower than measured for all of the crop treatments, averaging only $23 \mathrm{~kg} \mathrm{~N}^{-1}$ in 2018 and $13 \mathrm{~kg} \mathrm{~N} \mathrm{ha}^{-1}$ in 2019. The practise of lifting the FB crop in autumn appeared to have no consistent effect on recorded $\mathrm{N}$ leaching losses. Compared within any particular season, soil 

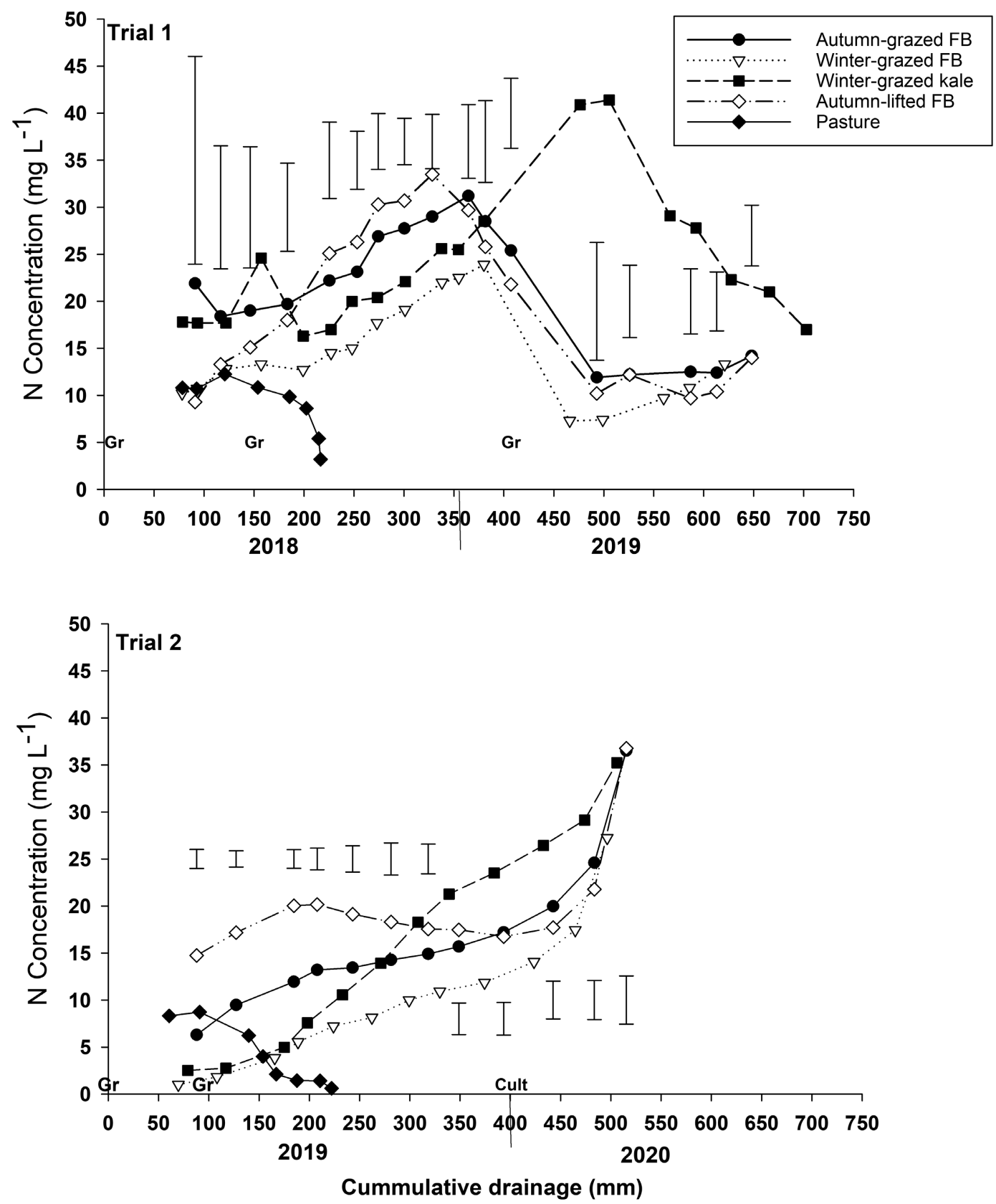

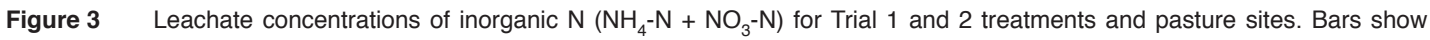
$\operatorname{LSD}_{(\mathrm{P}<0.05)}$ values for FB treatments in Trial 1 and for all crop treatments in Trial 2.

inorganic $\mathrm{N}$ contents measured at the time of treatment implementation generally showed a consistent relative treatment effect that matched observed $\mathrm{N}$ leaching losses. This was most evident in relative and absolute terms for the winter grazing treatments, and in relative terms for the imposed autumn treatments (Figure 4).

\section{Discussion}

Leaching losses from autumn-grazed or autumn-lifted FB treatments were large, both in absolute terms and relative to losses measured in the winter-grazed FB treatment. This is not altogether unexpected and most likely a consequence of leaving soil without plant 

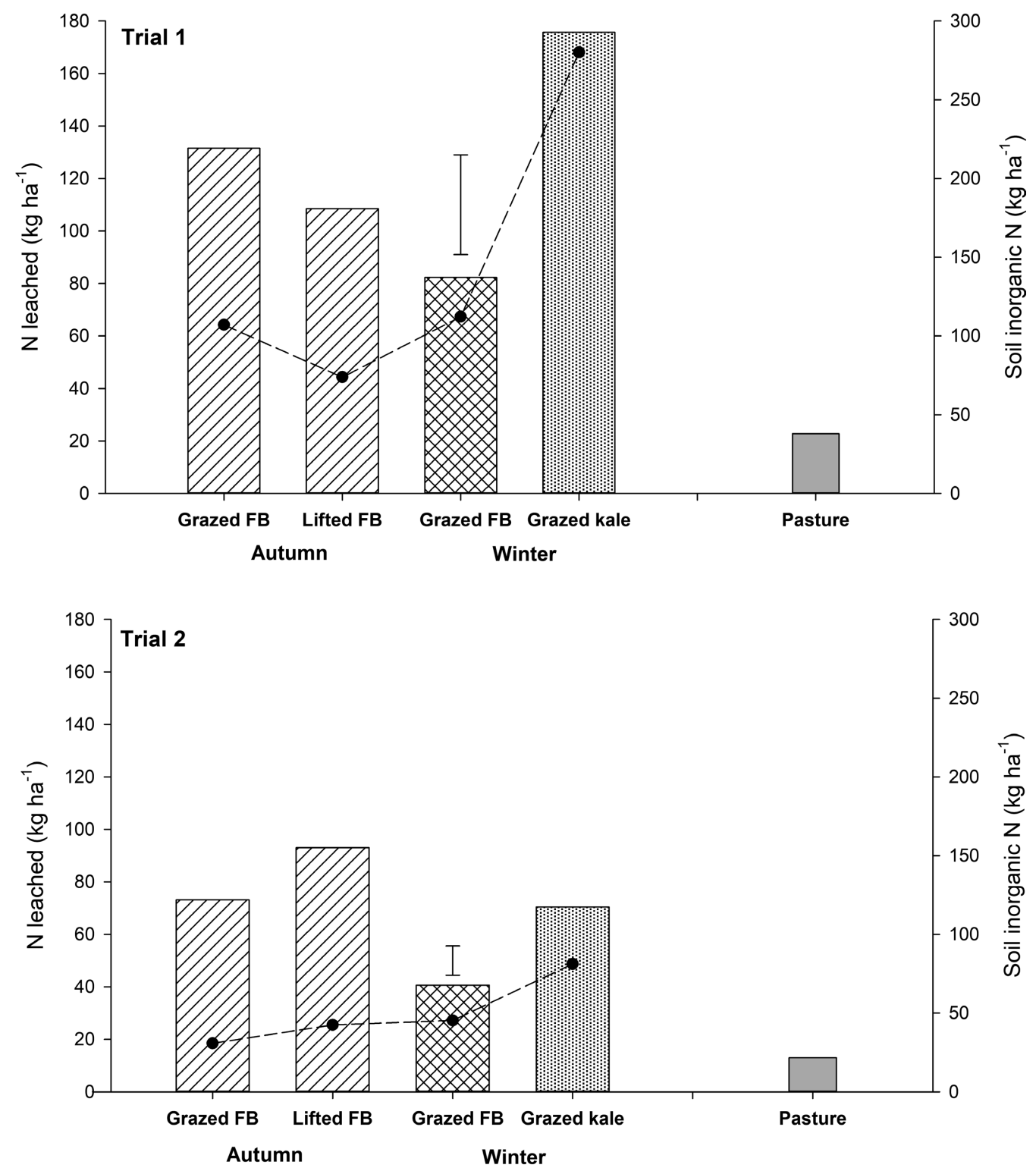

Figure 4 Inorganic $\mathrm{N}\left(\mathrm{NO}_{3}-\mathrm{N}+\mathrm{NH}_{4}-\mathrm{N}\right)$ leaching losses (bars) and soil inorganic $\mathrm{N}$ contents (dashed lines) for Trial 1 and Trial 2. Bars show LSD ${ }_{(\mathrm{P}<0.05)}$ values for $\mathrm{N}$ leached from FB treatments in Trial 1, and for all crop treatments in Trial 2.

cover for long periods over late autumn and winter before paddocks were re-planted the following spring. Measurements of soil inorganic $\mathrm{N}$ contents consistently showed that large amounts of ammonium- and nitrate-N remained following grazing and lifting of FB plants in autumn, likely providing the source of $\mathrm{N}$ measured in leachate over the subsequent drainage season. A peculiar aspect of our findings is the lack of any treatment effect on soil inorganic $\mathrm{N}$ contents or $\mathrm{N}$ leaching when $\mathrm{FB}$ plants were lifted in autumn. This practice was expected to reduce urinary $\mathrm{N}$ returns to the plots, and thus leave less $\mathrm{N}$ in soil that would be vulnerable to transport in drainage. The limited effect observed in both trials suggests that urinary $\mathrm{N}$ returns were less important in autumn-lifted FB treatments than we anticipated. On reflection, the timing, short duration, and consequently relatively low grazing intensity of autumn grazing (Table 1) supports the general conclusion that urinary $\mathrm{N}$ was a less important source of leached $\mathrm{N}$ than residual soil $\mathrm{N}$ that had not been taken up by the FB crop. This may also explain why leachate $\mathrm{N}$ concentrations were relatively high when drainage commenced in May, 
particularly in 2018 (Figure 3). Our findings indicate that any benefit arising from a reduction in urinary $\mathrm{N}$ excretion due to feeding FB in late lactation was outweighed by the risk posed by leaving soil bare over the following winter. This conclusion is supported by rough calculations of relative area and $\mathrm{N}$ contribution: despite accounting for just $0.6 \%$ of estimated farm area, based on the average of our 2 years of measured leaching data the autumn-lifted or grazed FB crop is estimated to have contributed approx. $2.5 \%$ of farmlet $\mathrm{N}$ leaching loss. Given lifting of FB did not appear to provide much additional benefit, other mitigation strategies such as the planting of catch crops (Malcolm et al. 2020) may need to be considered if reductions in $\mathrm{N}$ leaching are to be achieved on these (albeit relatively small) parts of the farming system.

Soil inorganic $\mathrm{N}$ contents under the kale treatments were considerably greater than measured for the winter-grazed FB treatment in both years of the study, indicating more $\mathrm{N}$ available to be leached. The large amount of soil $\mathrm{N}$ at depth observed in Year 1 of Trial 1 probably also reflects the effects that a very dry summer period in early 2018 had on soil $\mathrm{N}$ mineralisation rates, as noted above. Winter-deposited urine $\mathrm{N}$ took 12 to 16 months to leach below the 600 $\mathrm{mm}$ level of the ceramic cups (Figure 3 ) and generally displayed an elution pattern typical of well-structured soils with minimal preferential flow, increasing slowly over the spring period following winter application of urine $\mathrm{N}$ and often not peaking before drainage ended in November. Similarly, Smith et al. (2012) showed that $\mathrm{N}$ concentrations often peaked in the autumn and early winter of the year following winter deposition of urine.

As suggested by previous researchers (e.g. Malcolm et al. 2016; De Ruiter et al. 2019), N leaching from the winter-grazed FB treatment was less than observed from the winter-grazed kale treatment. While the design of Trial 1 prevented this being statistically analysed, results from experimentation in Trial 2 show that losses from these treatments were significantly different, despite not all the urine $\mathrm{N}$ being collected by the end of the drainage season. The $50 \%$ difference in $\mathrm{N}$ leached under FB in Trial 1 and $40 \%$ difference to date in Trial 2 (Figure 4) reflected the 40 to $45 \%$ reduction in $\mathrm{N}$ intakes estimated for the cows grazing FB in winter (Figure 2). This lower N intake in the winter-grazed FB treatment reflects its lower CP content (Table 2; Dalley et al. 2017; Waghorn et al. 2019) and consequently reduced $\mathrm{N}$ excretion. The leaching loss of $142 \mathrm{~kg} \mathrm{~N}$ $\mathrm{ha}^{-1}$ measured from the winter-grazed kale treatment in Trial 1 was particularly high when compared to previous measurements from brassica crops elsewhere in Southland (30-108 $\mathrm{kg} \mathrm{N} \mathrm{ha}^{-1}$; Monaghan et al. 2013; Smith et al. 2012) and may be at least partly attributable to the mineralisation of large amounts of soil organic $\mathrm{N}$ following the dry summer that preceded winter of Trial 1. The findings appear to support a role for plant secondary metabolites in voided urine or root exudates in reduced $\mathrm{N}$ leaching losses from the winter-grazed FB treatment in our study. In a laboratory study conducted at $10^{\circ} \mathrm{C}$, Yao et al. (2018) observed that the growth of ammonia-oxidising bacteria (AOB) was delayed in soil treated with urine obtained from cows grazing a FB diet. This delay was thought to contribute to the lower emissions of nitrous oxide observed in their study; such an effect may also partially explain the reductions in $\mathrm{N}$ leaching we observed. A similar inhibitory effect on soil nitrification rates was reported by Talbot et al. (2020) who found that urine from cattle fed on a FB diet resulted in less $\mathrm{N}$ leaching than urine from cows fed on pasture.

An important consideration that needs to be factored into calculations of the potential environmental impact of stock wintering is the reduced crop area required per animal if higher-yielding FB is used as a main winter crop instead of kale. Based on the crop yields and feeding regimens of our study (Table 1), we estimate that the area of FB crop area required would be approximately two-thirds of that required to winter an equivalent number of dairy cows on kale. Combining this reduced area with the reduced per hectare losses of $\mathrm{N}$ reported in Figure 4 suggests that $\mathrm{N}$ leaching losses per cow under a FB-wintering option would be about $35 \%$ of that estimated if a kale crop was chosen instead. Whilst these are preliminary estimates given Trial 2 leaching measurements are still to be fully completed, they demonstrate the importance of considering both required winter crop areas and the fluxes per unit area in any environmental analysis.

In contrast to losses from the crop paddocks, $\mathrm{N}$ leaching losses from the pasture paddocks grazed over the milking season averaged only $23 \mathrm{~kg} \mathrm{~N} \mathrm{ha}^{-1}$ in 2018 and $13 \mathrm{~kg} \mathrm{~N} \mathrm{ha}^{-1}$ in 2019. These lower $\mathrm{N}$ leaching losses under pasture reflect the capacity of the pasturebased grazing system to capture $\mathrm{N}$ when plant cover is complete and $\mathrm{N}$ uptake is actively occurring (Talbot et al. 2020). Removing cows from pasture over winter, as is the case in this situation, is also beneficial and limits urine $\mathrm{N}$ returns at times of low pasture growth. The relative importance of pasture versus winter crop area contributions to $\mathrm{N}$ leaching losses can be demonstrated for the SDH farm by calculating the proportional areas and $\mathrm{N}$ leaching losses estimated based on the results over three years presented here. We estimate that winter FB or kale crops occupy only $15 \%$ of land area, yet might contribute 33 to $50 \%$ of total farm losses for the two crops, respectively. This highlights the large contribution of winter crop grazing to $\mathrm{N}$ leaching losses from these types of dairy production systems. 


\section{Conclusions}

Leaching losses of $\mathrm{N}$ from $\mathrm{FB}$ and kale crops grazed by dairy cows are relatively large and can make a disproportionately large contribution to losses from the total dairy farm system. Preliminary findings indicate that the use of winter-grazed FB as an alternative to winter-grazed kale can be an important factor in limiting such winter $\mathrm{N}$ leaching losses. Greater N leaching was observed following grazing and/or lifting FB in autumn compared to grazing FB in winter. Grazing and/or harvest timing (autumn vs winter) as well as crop type are therefore important factors that determine $\mathrm{N}$ leaching losses from Southland dairy systems and need to be considered as part of a farm management system. Results from multiple years of measurements will be used to support and improve current modelling approaches for estimating $\mathrm{N}$ leaching losses from grazed dairy systems.

\section{ACKNOWLEDGEMENTS}

We would like to acknowledge the assistance of Tom Orchiston, Wayne Worth and staff from Woodlands Research Station and Environment Southland for installing the ceramic cups; Stuart Lindsey, Martin Kear and Moira Dexter for sample analysis; Dawn Dalley at DairyNZ for the provision of feed intake data; and the staff of SDH for assistance with treatment implementation. This research was funded by New Zealand dairy farmers through DairyNZ Inc. (contract CB1917)

\section{REFERENCES}

Dalley DE, Malcolm BJ, Chakwizira E, de Ruiter JM. 2017. Range of quality characteristics of the New Zealand forages and implications for reducing the nitrogen leaching risk from grazing dairy cows. New Zealand Journal of Agricultural Research 60: 319332. https://doi.org/10.1080/00288233.2017.13457 62

Dalley DE, Waugh D, Griffin A, Higham C, de Ruiter JM, Malcolm B. 2020. Productivity and environmental implications of fodder beet and maize silage as supplements to pasture for late lactation dairy cows. New Zealand Journal of Agricultural Research 61: 145-164. https://doi.org/10.1080/0028 8233.2019.1675717

de Klein CAM, van der Weerden TJ, Luo J, Cameron KC, Di HJ. 2020. A review of plant options for mitigating nitrous oxide emissions from pasturebased systems. New Zealand Journal of Agricultural Research 63: 29-43. https://doi.org/10.1080/002882 33.2019.1614073

De Ruiter JM, Malcolm BJ, Chadwizira E, Johnstone PR, Maley S, Arnold NP, Dalley DE. 2019. Crop management effects on supplementary feed quality and crop options for dairy feeding to reduce nitrate leaching. New Zealand Journal of Agricultural Research. 62: 369-398. https://doi.org/10.1080/0028 8233.2018.1508042

Di HJ, Cameron KC, Podolyan A, Edwards GR, de Klein CAM, Dynes R, Woods RR. 2016. The potential of using alternative pastures, forage crops and gibberellic acid to mitigate nitrous oxide emissions. Journal of Soils and Sediments 16: 22522262. https://doi.org/10.1007/s11368-016-1442-1

Drewry JJ, Paton RJ. 2000. The effects of cattle treading and natural amelioration on soil physical properties and pasture under dairy farming in Southland, New Zealand. New Zealand Journal of Agricultural Research 43: 377-386. https://doi.org/10.1080/0028 8233.2000 .9513438

FAO 2000. Crop Evapotranspiration. [FAO irrigation and drainage paper No. 56] Rome. Italy.

Gibbs SJ. 2014. Fodder beet in the New Zealand dairy industry. Proceedings of the South Island Dairy Event, Stadium Southland, Invercargill. pp. 237-246.

Gibbs SJ, Saldias B, Trotter C. 2015. Fodder beet in lactation and to replacement heifers. Proceedings of the South Island Dairy Event, Lincoln University. pp. 241-252.

Lilburne L, Carrick S, Webb T, Moir J. 2012. Computer-based evaluation of methods to sample nitrate leached from grazed pasture. Soil Use and Management 28: 19-26. https://doi.org/10.1111/ j.1475-2743.2011.00378.x

Malcolm BJ, de Ruiter JM, Dalley DE, Carrick S, Waugh D, Arnold NP, Dellow SJ, Beare MH, Johnstone PR, Wohlers M, Brown H, Welten B, Horrocks AJ. 2020. Catch crops and feeding strategy can reduce the risk of nitrogen leaching in late lactation fodder beet systems. New Zealand Journal of Agricultural Research 63: 44-64. https://doi.org/10.1080/002882 33.2019.1704422

Malcolm BJ, Cameron KC, Edwards GR, Di HJ, de Ruiter JM, Dalley D. 2016. Nitrate leaching losses from lysimeters simulating winter grazing of fodder beet by dairy cows. New Zealand Journal of Agricultural Research 59: 194-203. https://doi.org/1 0.1080/00288233.2016.1150307

Malcolm BJ, Cameron KC, Edwards GR, Di HJ. 2015. Nitrate leaching losses from lysimeters containing winter kale: the effects of urinary $\mathrm{N}$ rate and DCD application. New Zealand Journal of Agricultural Research 58: 13-25. https://doi.org/10.1080/002882 33.2014 .961644

Moir JL, Cameron KC, Di HJ, Fertsak U. 2011. The spatial coverage of dairy cattle urine patches in an intensively grazed pasture system. Journal of Agricultural Science 149: 473-485. https://doi. org/10.1017/S0021859610001012 
Monaghan RM, Smith LC, de Klein CAM. 2013. The effectiveness of the nitrification inhibitor dicyandiamide (DCD) in reducing nitrate leaching and nitrous oxide emissions from a grazed winter forage crop in southern New Zealand. Agriculture Ecosystems and Environment. 175: 29-38. https:// doi.org/10.1016/j.agee.2013.04.019

Mulvaney RL. 1996. Nitrogen-inorganic forms. In Sparks D.L. (Ed.) Methods of Soil Analysis: Part 3. [Book Series 5]. Madison, WI, USA: Soil Science Society of America. pp. 1123-1184. https://doi. org/10.2136/sssabookser5.3.c38

Parker, WJ. 1998. Standardisation between livestock classes: the use and misuse of the stock unit system. Proceedings of the New Zealand Grassland Association 60: 243-248. https://doi.org/10.33584/ jnzg.1998.60.2277

Ravera BL, Bryant RH, Cameron KC, Edwards GR, Smith N. 2015. Use of a urine meter to detect variation in urination behaviour of dairy cows on winter crop. Proceedings of the New Zealand Society of Animal Production 75: 84-88.

Rayment GE, Lyons DJ. 2011. Total soil N - Dumas high-temperature combustion. Chapter 7, method A5. Soil Chemical Methods - Australia: CSIRO Publishing. https://doi.org/10.1071/9780643101364

Smith LC, Orchiston T, Monaghan RM. 2012. The effectiveness of the nitrification inhibitor dicyandiamide (DCD) for mitigating nitrogen leaching losses from a winter-grazed forage crop on a free draining soil in northern Southland. Proceedings of the New Zealand Grassland Association 74: 3977. https://doi.org/10.33584/jnzg.2012.74.2882

Talbot WD, Malcolm BJ, Cameron KC, Di HJ, Whitehead D. 2020. Cattle diet and winter plant growth effects on nitrogen losses from cattle urine patches. Nutrient Cycling in Agroecoststems.116: 365-379. https://doi.org/10.1007/s10705-020-100504

Waghorn GC, Law N, Bryant M, Pachero D, Dalley D. 2019. Digestion and nitrogen excretion by HolsteinFriesian cows in late lactation offered ryegrass-based pasture supplemented with fodder beet. Animal Production Science 59: 1261-1270. https://doi. org/10.1071/AN18018

Webster DM, Shepherd MA, Goulding KWT, Lord EI. 1993. Comparison of methods for measuring the leaching of mineral nitrogen from arable land. Journal of Soil Science 44: 49-62. https://doi. org/10.1111/j.1365-2389.1993.tb00433.x

Yao B, Di HJ, Cameron KC, Podolyan A, Shen J, He J. 2018. Understanding the mechanisms for the lower nitrous oxide emissions from fodder beet urine compared with kale urine from dairy cows. Journal of Soils and Sediments 18: 85-93. https://doi. org/10.1007/s11368-017-1780-7 